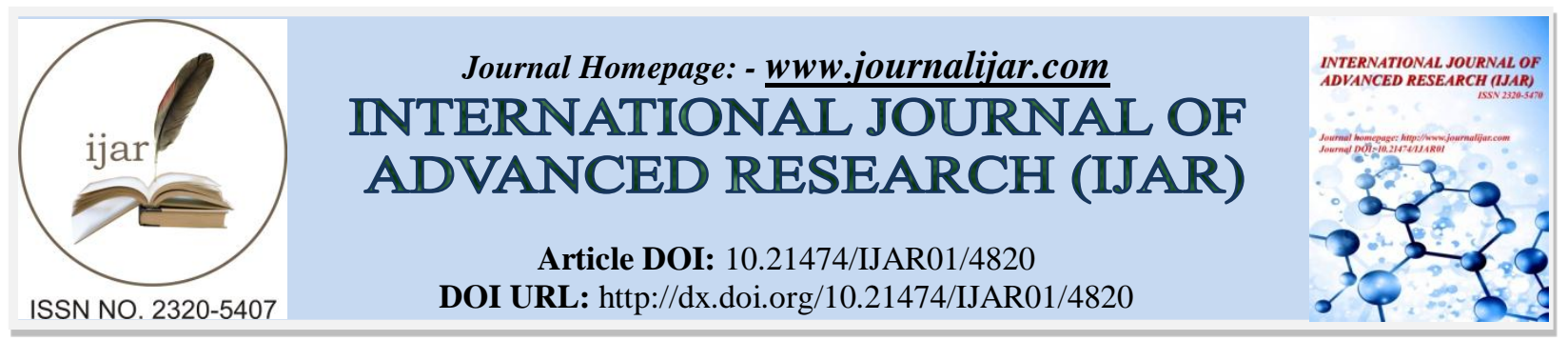

RESEARCH ARTICLE

\title{
ACUTE TOXICITY AND PATHOLOGICAL EFFECT OF ANNONA SQUAMOSA SEED AND LEAF EXTRACTS ON THE TISSUES OF CYPRINUS CARPIO.
}

\author{
"Syeda Hina Kauser ${ }^{1}$, Shoeiba Tasneem ${ }^{1}$ and Rafath Yasmeen ${ }^{2}$. \\ 1. Ph.D. Research Scholar, Department of Zoology, Osmania University, Hyderabad, Telangana, India. \\ 2. Assistant Professor, Department of Zoology, Osmania University, Hyderabad, Telangana, India.
}

\section{Manuscript Info}

(.........................

Manuscript History

Received: 11 May 2017

Final Accepted: 13 June 2017

Published: July 2017

Key words:-

Annona squamosa, Cyprinus carpio, aqueous extract, gill, intestine.

\section{Abstract}

Toxicity assessment of aqueous extracts of dried leaf and seeds of Annona squamosa to common carp - Cyprinus carpio. It's a plant well known for its insecticidal and pesticidal efficacy. The $96 \mathrm{hr}$ Lc50 value of aqueous leaf and seed extracts obtained was 300ppm and 70ppm respectively. $1 / 10^{\text {th }}$ of the $\mathrm{Lc50}$ value i.e., $30 \mathrm{ppm}$ and $7 \mathrm{ppm}$ respectively for leaf and seed extracts was taken as sub-lethal concentrations. Fishes were exposed to the respective sub-lethal concentrations for the period of 14 days. At the end of $7^{\text {th }}$ day and $14^{\text {th }}$ day of exposure the gill and intestine were collected from exposed and control fishes. The tissues were processed and sectioned at $4 \mu \mathrm{m}$, stained with Haematoxylin-Eosin and finally the obtained slides were observed under light microscope at 40x magnification and photographed. The pathological changes in gills of exposed fishes include fused gill lamellae, inflammatory cells and distortions in the primary and secondary gill lamellae. The changes in intestine are occurrence of lesions, disruption of villi epithelium, infiltration of inflammatory cells through the villi and necrosis. The histological changes observed were mild in leaf extract exposed tissues but severe alterations occurred in fish tissues on exposure to Annona seed extract.

Copy Right, IJAR, 2017,. All rights reserved.

\section{Introduction:-}

The aquatic ecosystem as a part of natural environment is also faced with the threat of shrinkage in genetic base and biodiversity due to indiscriminate use of pesticides (Omitoyin et al., 2006). Due to the long term persistence of synthetic pesticides in water and fish body, the quality of fish and its status is getting adversely affected (Cullen and Connell, 1992; Waliszewski et. al., 1999). In view of the hazards associated with the use of synthetic chemical pesticides or insecticides, there has been urge to explore suitable alternatives for pest control. Screening of plant extracts for deleterious effect on insects is one of the approaches in search of novel biological insecticides (Ismam, M.B., 1991). Insecticidal activity of many plants against several insects has been demonstrated (Singh and Jain, 1987; Carlini and Grossi-de, 2002)). Seed as well as the foliar extracts of several plants are reported to have toxic and potent growth inhibitor activity to insects (Champagne et. al., 1993).

Annona squamosa is a member of the family Annonaceae of custard apple trees mostly known for its edible fruits Annona (Shahnaj Parvin et al., 2003). Annonaceae family consists of tropical trees and shrubs comprising about 130 
genera and 2300 species. Plants of this family have been traditionally used as insecticides (Castillo et al., 2010). Annonaceous acetogenins have attracted much interest due to their broad range of biological activities (Alali et al., 1999). The acetogenins extracted from the tree leaves and seeds have potent pesticidal and insecticidal properties (Rupprecht et al., 1990). The powdered seed and leaf extracts of this plant species are used to destroy insect, pests, also as repellants and anti-feedants. More than twenty acetogenins from the seeds of Annona squamosal L. are known among which the squamosin-3 and squamostatin-A were two major constituents (Fujimoto et al., 1988; 1990; 1994; Sahai et al., 1994; Araya et al., 1994a,b). Due to the presence of biologically active compounds acetogenins or squamosin the seeds of A.squamosa are reported to possess insecticidal and abortifacient traits (Chopra et al., 1986).

Fishes serve as bio-indicators of environmental pollution hence are used for quality assessment of aquatic environment (Lopes et al., 2001; Whitefield and Elliott, 2002 and Dautremepuits et al., 2004). The fish species Cyprinus carpio (Linn.) was chosen for this work based on its following favorable features. The common carp (Cyprinus carpio) has been one of the oldest domesticated species of fish for food (Balon, E.K., 2006). It commands very high commercial value in our markets due to its ability to adapt readily to controlled conditions, remarkable fast growth rate, acceptability and high feed conversion ratio, tolerance to crowded conditions and its quality flesh. C.carpio has the potential to survive fluctuations in the climatic conditions and is found to be most suitable for various farming practices (Jain, 2002).

The present research work was undertaken to investigate the acute toxicity and toxic effect of aqueous extracts of Annona squamosa leaves and seeds on the histology of gills and intestinal tissues of exposed Cyprinus carpio.

\section{Materials and Methods:-}

Fish:- The fresh water fish Common carp- Cyprinus carpio ranging $10 \pm 0.5 \mathrm{cms}$ in total length and $8 \pm 0.25$ grams in weight were collected from kolsagar reservoir, Mahabubnagar, Telangana; India. The fishes were transported to the laboratory and were stocked up in 500 liter capacity tank having dechlorinated tap water and were acclimatized for about 20 days. The fishes were fed twice daily with commercially available fish feed pellets throughout the acclimatization period and the water was renewed every $24 \mathrm{hrs}$.

Preparation of aqueous leaf and seed extracts:- Annona squamosa L. (Family: Annonaceae) plant leaves were collected from Botanical Garden of Osmania University College for Women; Hyderabad; Telangana; India and seeds from the locally available fruits of the plant and was identified by plant taxonomist, Department of Botany; Osmania University; Hyderabad; Telangana; India. Fresh seeds and leaves of the plant were collected and washed in tap water and dried in shade for ten days. After complete drying, the seeds and leaves were pulverised to fine powder in electric blender. 5\% of aqueous leaf extract was prepared by dissolving 50grams of powdered seeds and leaves in 1 liter of distilled water each in separate containers and kept at room temperature for 24hrs with intermittent shaking. After $24 \mathrm{hrs}$ each mixture was filtered and the extracts were used immediately in the experiment (Saravanan, et. al., 2010).

\section{Determination of $96 \mathrm{hr}$ lc50 and sub-lethal toxicity testing:-}

For Lc50 testing the fishes were divided into 20 groups, each group having 10 fishes in glass aquaria provided with 15 litres of de-chlorinated tap water. $24 \mathrm{hrs}$ prior the commencement of Lc50 testing the fishes were stopped feeding. The 10 groups were used to study the Lc50 of Annona squamosa leaf extract. The concentration of leaf extract taken in aquaria was 100ppm, 150ppm, 200ppm, 250ppm, 300ppm, 350ppm, 400ppm, 450ppm and 500ppm respectively and one group served as control with no extract. Other 10 groups were used to study the $96 \mathrm{hr}$ Lc50 of Annona squamosa seed extract. The aquaria were having the seed extract in the concentration of 30ppm, 40ppm, 50ppm, 60ppm, 70ppm, 80ppm, 90ppm, 100ppm and 110ppm respectively and one group was kept as control. Throughout the 96hr Lc50 testing the fishes were observed for clinical signs like skin pigmentation, swimming patterns, response to stimuli and mortality. The $96 \mathrm{hr}$ Lc50 value for both the leaf and seed extracts were recorded and tested by probit analysis as described by Finney (1971).

$1 / 10^{\text {th }}$ of the $96 \mathrm{hr}$ Lc50 value was taken as the sub-lethal concentration, i.e. 30ppm for leaf and $7 \mathrm{ppm}$ for seed extract respectively. The fishes were exposed to both the leaf and seed extracts sub-lethal concentrations separately in group of 10 fishes each for a period of 14 days. Throughout the sub-lethal exposure period the fishes were fed with the commercial fish feed pellets twice daily and the water was renewed along with respective concentrations after every $24 \mathrm{hrs}$. One group of fish did not receive any extract and this group served as the control. After the completion of 7 and 14 days the fishes from both the exposure groups and also the control group were randomly 
selected and the gill and intestine were carefully dissected out, washed in $0.9 \%$ saline and were then fixed in $10 \%$ formalin for $24 \mathrm{hrs}$. After $24 \mathrm{hrs}$ the tissue were dehydrated in the graded series of ethanol, embedded in paraffin and sectioned at $4 \mu \mathrm{m}$ and stained with Mayer's Haematoxylin-Eosin stain. The slides were observed under light microscope at 40x magnification and were photographed with Olympus digital camera attached to the microscope.

\section{Results:-}

The Lc50 values of Annona squamosa aqueous leaf and seed extracts for the fish Cyprinus carpio obtained after 96hrs was $300 \mathrm{ppm}$ and $70 \mathrm{ppm}$ respectively. $1 / 10^{\text {th }}$ of the Lc50 value i.e., $30 \mathrm{ppm}$ and $7 \mathrm{ppm}$ were taken as sub-lethal concentration for aqueous leaf and seed extracts respectively, to investigate the histopathological changes in the gill and intestine after the completion of 7 and 14 days of exposure periods. The results of exposed were compared with controls.

Table 1:- Annona squamosa aqueous leaf extract concentration and fish mortality at 96 hours, in LC50 experiments.

\begin{tabular}{|c|c|c|c|c|}
\hline $\begin{array}{c}\text { Sl. } \\
\text { No. }\end{array}$ & $\begin{array}{c}\text { Concentration of A.squamosa aqueous leaf } \\
\text { extract (ppm) }\end{array}$ & $\begin{array}{c}\text { No. of fishes } \\
\text { exposed }\end{array}$ & $\begin{array}{c}\text { No. of fishes } \\
\text { dead }\end{array}$ & $\begin{array}{c}\% \\
\text { Mortality }\end{array}$ \\
\hline 1. & 0 & 10 & 0 & 0 \\
\hline 2. & 100 & 10 & 1 & 10 \\
\hline 3. & 150 & 10 & 1 & 10 \\
\hline 4. & 200 & 10 & 2 & 20 \\
\hline 5. & 250 & 10 & 4 & 40 \\
\hline 6. & 300 & 10 & 5 & 50 \\
\hline 7. & 350 & 10 & 6 & 60 \\
\hline 8. & 400 & 10 & 8 & 80 \\
\hline 9. & 450 & 10 & 10 & 100 \\
\hline 10. & 500 & 10 & 10 & 100 \\
\hline
\end{tabular}

Table 2:- Annona squamosa aqueous seed extract concentration and fish mortality at 96 hours, in LC50 experiments.

\begin{tabular}{|c|c|c|c|c|}
\hline Sl. No. & $\begin{array}{c}\text { Concentration of A.squamosa } \\
\text { aqueous seed extract (ppm) }\end{array}$ & No. of fishes exposed & No. of fishes dead & \% Mortality \\
\hline 1. & 0 & 10 & 0 & 0 \\
\hline 2. & 30 & 10 & 1 & 10 \\
\hline 3. & 40 & 10 & 2 & 20 \\
\hline 4. & 50 & 10 & 2 & 20 \\
\hline 5. & 60 & 10 & 4 & 50 \\
\hline 6. & 70 & 10 & 5 & 70 \\
\hline 7. & 80 & 10 & 7 & 80 \\
\hline 8. & 90 & 10 & 8 & 80 \\
\hline 9. & 100 & 10 & 10 & 100 \\
\hline 10. & 110 & 10 & 8 & \\
\hline
\end{tabular}

\section{Histology of gill:}

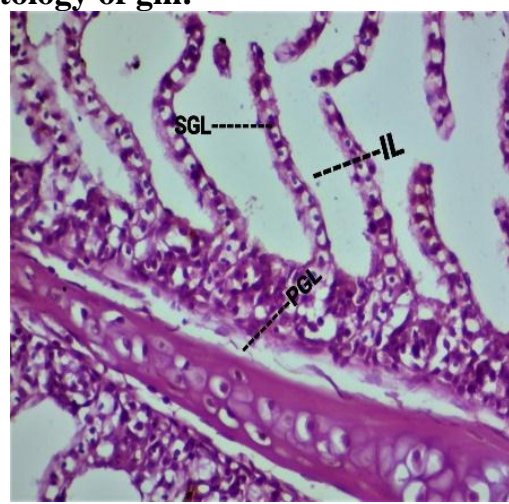

Fig:1

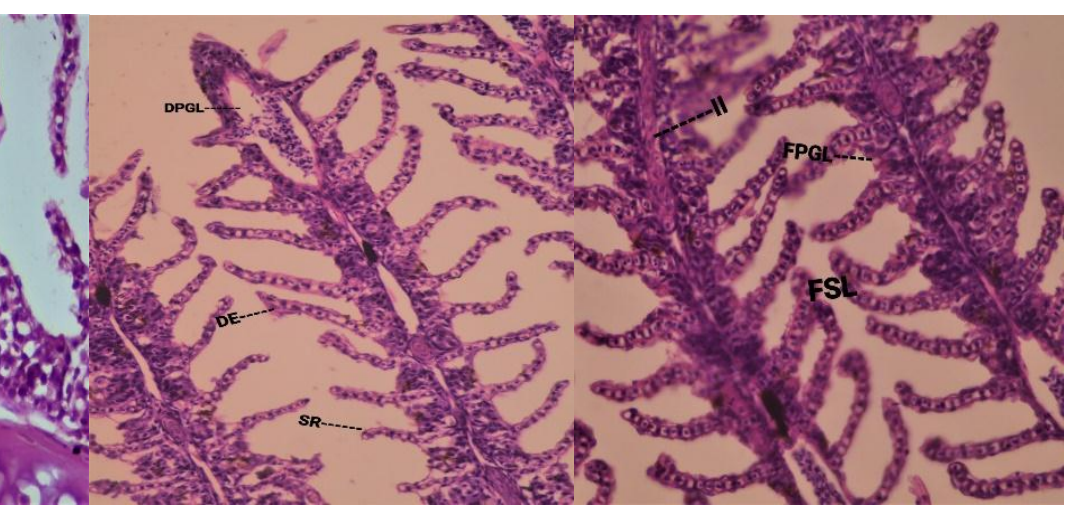

Fig:2
Ffig:3 


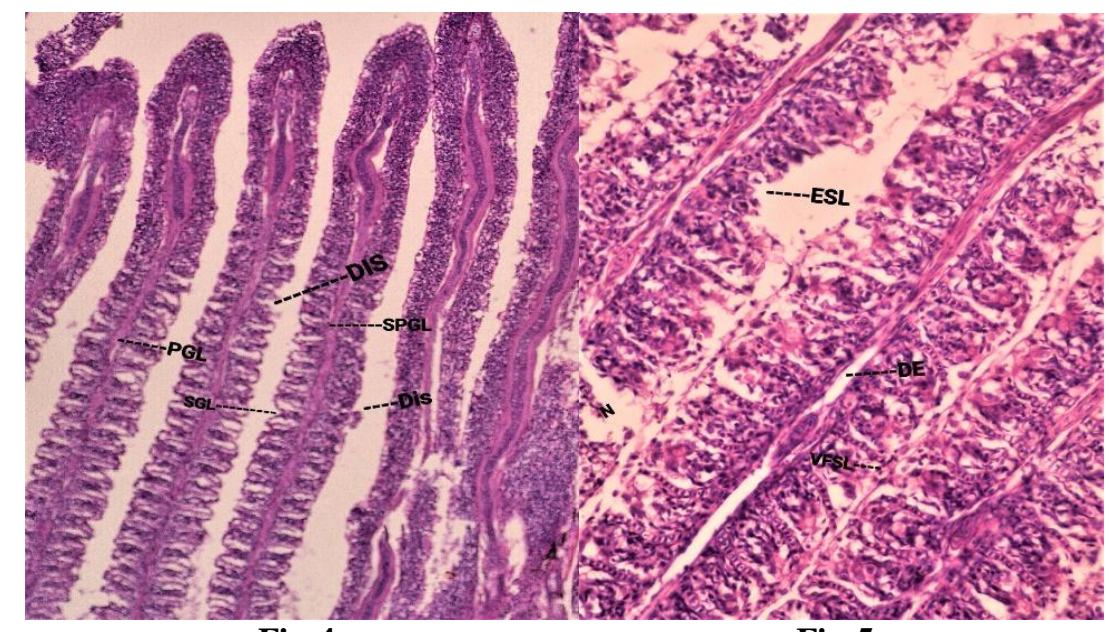

Fig:4

Fig:5

Fig: 1; normal gill- SGL (secondary gill lamellae), IL (inter lamellar region), PGL (primary gill lamellae).

Fig: 2; gill of fish exposed to A.squamosa aqueous leaf extract $7^{\text {th }}$ day-DPGL (dilation of primary gill lamellae), DE (disruption of epithelium), SR (size reduction).

Fig: 3; gill of fish exposed to A.squamosa aqueous leaf extract $14^{\text {th }}$ day- II (infiltration of inflammatory cells), FPGL (fibrosis of primary gill lamellae), FSL (fusion of secondary gill lamellae).

Fig: 4; gill of fish exposed to A.squamosa aqueous seed extract $7^{\text {th }}$ day- PGL (primary gill lamellae), SGL (secondary gill lamellae), DIS (distortion), SPGL (shrunken primary gill lamellae).

Fig: 5; gill of fish exposed to A.squamosa aqueous seed extract $14^{\text {th }}$ day- ESL (erosion of secondary gill lamellae), DE (degeneration of epithelium), N (necrosis), VFSL (vacuolation and fusion of secondary lamellae).

Normal gill:- (fig: 1) consist of four branchial arches below the operculum. Each branchial arch bears two hemibranches consisting of two rows of tapered and flattened primary gill lamellae (PGL), arranged parallel to one another and perpendicular to the arch. The respiratory surface comprising series of flattened leaf like structures called secondary gill lamellae (SGL) are located on the upper and lower surfaces of each PGL. The epithelial wall of SGL is held apart and supported by pillar cells. Between the two adjacent SGL lies the inter-lamellar region (IL).

Histological alterations in the Gill of Cyprinus carpio exposed to A.squamosa aqueous leaf extract:- At the end of 7 days of exposure the gill showed following changes (Fig.2) exhibiting dilation of primary gill lamellae (DPGL), size reduction (SR) of SGL, massive infiltration of inflammatory cells in the primary gill lamellae and secondary gill lamellae, disruption of epithelial cells (DE) of SGL. The 14 day exposure to sub-lethal concentration showed the following changes (Fig.3): Massive infiltration of inflammatory cells in PGL, mild dilation of SGL, fusion of secondary gill lamellae and fibrosis of primary gill lamellae.

Histological alterations in the Gill of Cyprinus carpio exposed to A.squamosa aqueous seed extract:- The 7 day exposure showed (Fig.4) primary gill lamellae shrunken and vacuolated, distortion of histological structures, mild infiltration of inflammatory cells throughout SGL. The 14 day exposure shows (Fig.5) erosion of secondary gill lamellae including degeneration of epithelium. Severe necrosis and vacuolar degeneration in SGL. 
Histology of Intestine:-

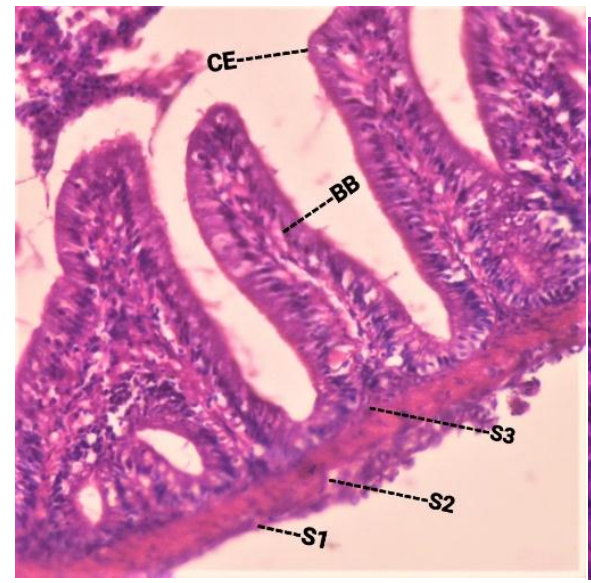

Fig:6

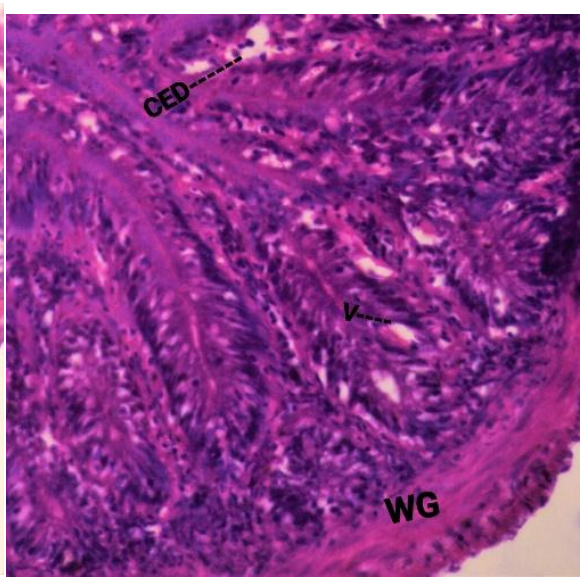

Fig:7

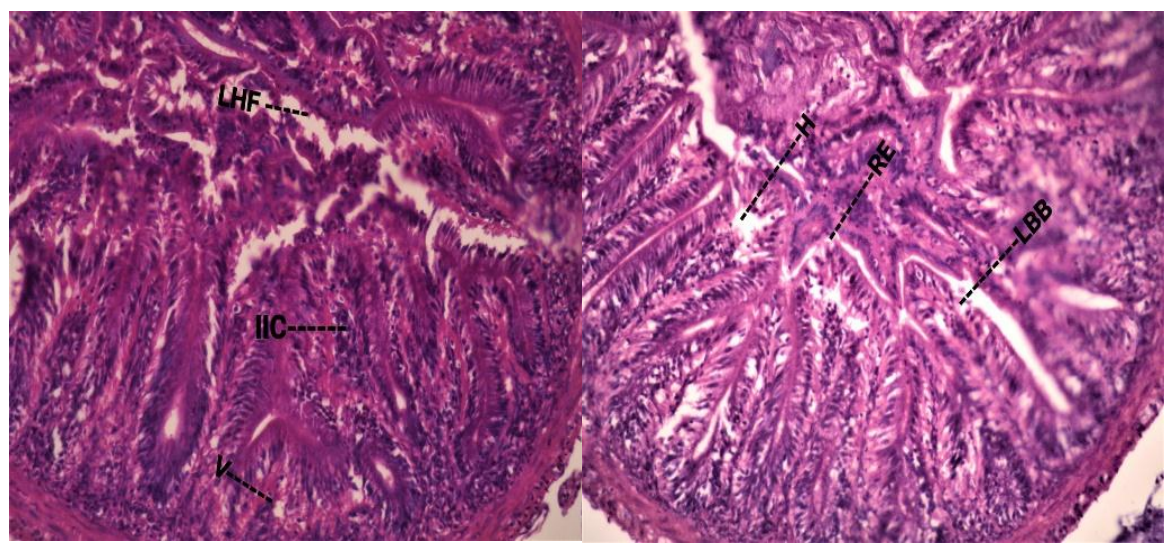

Fig:8

Fig:9

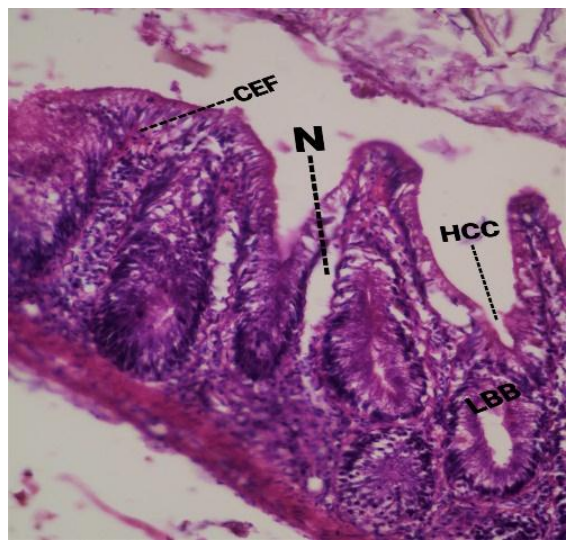

Fig:10

Fig: 6 normal intestine- CE (columnar epithelium), BB (brush border), S1 (serosa), S2 (sub mucosa), S3 (mucosa).

Fig: 7 intestine of fish exposed to A.squamosa aqueous leaf extract $7^{\text {th }}$ day- V (Vacuolation), CED (columnar epithelial disruption), WG (wide gap).

Fig: 8 intestine of fish exposed to A.squamosa aqueous leaf extract $14^{\text {th }}$ day- LHF (loss of histological features), IIC (infiltration of inflammatory cells), $\mathrm{V}$ (vacuolation).

Fig: 9 intestine of fish exposed to A.squamosa aqueous seed extract $7^{\text {th }}$ day- H (histolysis), RE (rupture of epithelium), LBB (loss of brush border).

Fig: 10 intestine of fish exposed to A.squamosa aqueous seed extract $14^{\text {th }}$ day- N (necrosis), CEF (columnar epithelial fusion), LBB (loss of brush border), HCC (histolysis of columnar cells). 
Normal Intestine: (fig: 6):-

Outer layer is the serosa (S1) with single layer of epithelial cells followed by sub-serosa or muscularis layer (S2) consisting of smooth muscle fibres arranged in definite pattern, the outer being longitudinal and inner circular. Submucosa (S3) consists of connective tissue fibres blood vessels and nerve endings. Gastric mucosa (M) is folded into a number of finger like processes- the intestinal villi, having columnar epithelium.

Histological alterations in the intestine of fish exposed to A.squamosa aqueous leaf extract:-

After 7 days of exposure (Fig.7) intestine showed disintegration of columnar epithelial cells, inflammatory cells present at the base of the villi, disruption of epithelial cells, wide gap between muscularis and villi, and vacuolation. The intestine after 14 day exposure shows (Fig.8) loss of histological features, vacuolation and infiltration of inflammatory cells throughout the villi.

\section{Histological alterations in the intestine of fish exposed to A.squamosa aqueous seed Extract:-}

The 7 day exposure intestine histology shows (Fig.9) histolysis, rupture of epithelium and loss of brush border in proximal convoluted tubules. The changes after 14 day exposure in kidney includes (Fig.10) vacuolar degeneration of epithelial cells of villi, necrosis and loss of brush border, fusion of columnar epithelial cells and histolysis of columnar cells.

\section{Discussion:-}

Gill is the easily affected target organ when fish is exposed to pesticide or any other toxicant. In the present study the pathological alterations induced by A.squamosa leaf and seed extracts in the gills of Cyprinus carpio were characterized by distortion of secondary gill lamellae, histolysis, vacuolization, erosion of SGL, necrosis and fusion of secondary gill lamellae. Similar results were reported by Tilak and Yacobu (2002) showing gill damage in Fenvalerate treated C. idellus and by Tennyson et al., (2008) on exposure to Azadirachtin in Clarias gariepinus.

The fish intestine, in addition to digesting and absorbing feed, also plays important role in water and electrolyte balance; endocrine regulation of digestion and immunity (Buddington et al., 1997). The present study showed that damage in the kidney were more severe in the seed extract exposed fish. The histopathological changes observed in the intestine due to Annona squamosa leaf and seed extracts are the loss of brush border, vacuolation, degeneration of the epithelium of the intestinal villi. These findings are also been reported in fishes exposed to various toxicants. Suchismita and Abhik Gupta (2013) have also observed similar pathological lesions in the intestine of Esomus danricus treated with malathion. Sudha Singh and Asha Mehrotra (1999) have noted similar pathological lesions of carbaryl treated Nandus nandus.

\section{Conclusion:-}

The toxicity tests showed that Cyprinus carpio has high sensitivity to extracts of Annona squamosa evaluated in this study, even the sub lethal concentrations showed pathological effect on the vital organs of the exposed fish. The 96hrs Lc50 to C. carpio indicates that extracts are toxic to fish suggesting that even at low concentration it may cause the adverse effects. Thus the information obtained through present findings may be helpful for safe usage of the plant products.

\section{Acknowledgement:-}

Syeda Hina Kauser is thankful to UGC-BSR fellowship and Shoeiba Tasneem is thankful to UGC-MANF fellowship for financial assistance throughout the research. Authors are grateful to the department of zoology, Osmania University for providing animal house and lab facility.

\section{References:-}

1. Alali, F.Q., Liu, X.X. and McLaughlin, J.L. (1999). Annonaceous acetogenins: recent progress. Journal of Natural Products. 62(3): 504-540.

2. Araya, H., Hara, N., Fujimoto, Y., Srivastava, A. and Sahai, M. (1994-a). Squamosten-A, a novel tetrahydrofuranic acetogenin with a double bond in the hydrocarbon chain, from Annona squamosa L. Chem. Pharm. Bull. 42: 388-391.

3. Araya, H., Hara, N., Fujimoto, Y., Sahai, M., (1994-b). Squamostenal-A, apparently derived from tetrahydrofuranic acetogenin, from Annona squamosa. Biosci. Biotech. Biochem. 58: 1146-1147. 
4. Balon, E.K. (2006). The oldest domesticated fishes and the consequences of an epigenetic dichotomy in fish culture. Aqua. International Journal of Ichthyology. 11(2): 47-86.

5. Buddington, R.K., Krogdahl, A., and Bakke-McKellep, A.M. (1997). The intestine of carnivorous fish: structure and functions and the relations with diet. Acta Physiol Scand Suppl. 638: 67-80.

6. Carlini, C. R. and Grossi-de Sa MF. (2002). Plant toxic proteins with insecticidal properties- a review on the potentialities as bioinsecticides. Toxicon. 40: 1515-1539.

7. Castillo, L.E., Jimenez, J.J. and Delgado, M.A. (2010). Secondary metabolites of the Annonaceae, Solanaceae and Meliaceae families used as biological control of the insects. Tropical and Subtropical agroecosystems. 12: 445-462.

8. Champagne, D. E., Ismam, M. B., Downum K. R. and Towers, G. H. N. (1993). Insecticidal and growth reducing activity of foliar extracts from Meliaceae. Chemoecology. 4: 165-173.

9. Chopra, R.N., Nayar, S.L. and Chopra, I.C. (Eds). (1956) Glossary of Indian medicinal plants. C.S.I.R.. New Delhi. pp-20.

10. Cullen, M. C. and Connell, D. W. (1992). Bioaccumulation of chlorohydrocarbon pesticide by fish in the natural environment. Chemosphere. 25: 1579-1587.

11. Dautremepuits, C., Paris Palacios, S., Betoulle, S. and Vernet, G. (2004). Modulation in hepatic and head kidney parameters of carp (Cyprinus carpio. Linn) induced by copper and chitosan. Com. Biochem. Physiol. C. Toxicol. Pharmocol., 137: 325-333.

12. Finney, D. J (1971). "Probit Analysis"' $3^{\text {rd }}$ Ed., Cambridge Univ. Press, London/New York.

13. Fujimoto, Y., Eguchi, T., Kakinuma, K., Ikekawa, N., Sahai, M. and Gupta, Y.K. (1988). A new bistetrahydrofuran containing acetogenin from Annona squamosa. Chem. Pharm. Bull. 36(12): 4802-4806.

14. Fujimoto. Y., Murasaki, C., Kakinuma, K., Eguchi, T., Ikekawa, N., Furuya, M., Hirayama, K., Sahai, S., Gupta, Y.K. and Ray, A.B. (1990). Squamosatin-A: unprecedented bis-tetrahydrofuran acetogenin from Annona squamosa. Tetrahedron Lett. 31: 535-538.

15. Fujimoto, Y., Murasaki, C., Shimada, H., Nishioka, H., Kakinuma, K., Singh, S., Gupta, Y.K. and Sahai, M. (1994). Annonaceous Acetogenins from the seeds of Annona squamosa., non-adjacent bis-tetrahydrofuranic Acetogenins. Chem. Pharm. Bull. 42: 1175-1184.

16. Ismam, M.B. (1995). Leads and prospects for the development of new botanical insecticides. In: Reviews in pesticide toxicology (Roe, R. M. and Khur, R. J. eds). 3: 1-20.

17. Jain, Z. (2002). Status of carp varieties under culture in China. Aquaculture Asia. 7(1): 27-28.

18. Lopes, P.A., Pinheiro,T., Santos, M.C., da Luz Mathis, M., Collares Perira, M.J., and Viegas Crespo A.M. (2001). Response of antioxidant enzymes in the fresh water fish populations (Leuciscus alburnoides complex) to inorganic pollutants exposure. Sci. Total Environ. 280:153-163.

19. Omitoyin, B. O., Ajani, E. K., Adesina, B. T., and Okuagu, C. N. F. (2006). Toxicity of Lindane (Gamma Hexachloro-Cyclohexane) to Clarius gariepinus (Burchell, 1822). World Journal of Zoology. 1(1): 57-63.

20. Rupprecht, J. K., Hui, Y.H., McLaughlin, J.L. (1990). Annonaceous Acetogenins: J Nat Prod. 53:237-276.

21. Sahai, M., Singh, M., Gupta, Y.K., Akashi, S., Yuji, R., Hirayama, K., Asaki, H., Araya, H., Hara, N., Fujimoto, Y. (1994). Annonaceous Acetogenins from the seeds of Annona squamosa. Adjacent bistetrahydrofuran acetogenins. Chem. Pharm. Bull. 42: 1163-1174.

22. Saravanan. M; Vasantha Kumar. D, Malarvizhi. A and Ramesh. M. (2010). Biosafety of Azardirachta indica (A.Juss) leaves extracts on certain biochemical parameters in Labeo rohita. Journal of Biopesticides. 3(Special issue): 227-231.

23. Shahnaj Parvin, Mst., Ekramul Islam, M., Motiur Rahman, Md. and Ekramul Haque, Md. (2003). Toxicological evaluation of Annotemoyin-1 isolated from Annona squamosa Linn. on long Evan's rats. Pakistan journal of Biological Sciences. 6(18): 1593-1596.

24. Singh D., Jain, D. C. (1987). Relative toxicity of various organic solvents generally used in screening plant product for insecticidal activity against house fly (Musca domestica L.). Ind J Exp Biol. 25: 560-570.

25. Suchismita Das and Abhik Gupta (2013). Histopathological changes in the intestine of Indian flying barb ( Esomus danricus)exposed to organophosphate pesticide, malathion (EC 50). J B.A.H.S., 2(2): 90-93.

26. Sudha Singh and Asha Mehrotra. (1999). Histopathological changes induced by carbaryl in the intestine of freshwater fish, Nandus nandus.

27. Tennyson, S., Velmurugan, B., Thresia Mathews K. and John William, S. (2008). Impact of biopesticide Azadirachtin on fresh water catfish Clarias gariepinus (Burchell). Poll. Res. 27(1): 103-106.

28. Tilak, K.S. and Yacobu, K. (2002). Toxicity and effect of fenvalerate on fish Ctenopharyngodon idellus. J. Ecotoxicol. Environ. Monit. 12(1): 9-15. 
29. Waliszewski, S. M., Aguirre, A. A., Benitz, A., Infanzon, R. M., Infanzon, R. and Rivera, J. (1999). Organochlorine pesticides residues in human blood serum of inhabitants of Veracr Mexico. Bulletin of environmental contamination and Toxicology. 62: 397-402.

30. Whitefield, A.K. and Elliott, M., (2002). Fishes as indicators of environmental and ecological changes within estuaries; a review of progress and some suggestions for the future. J fish Biol. 61(1): 220-250. 